\title{
RHOJ Gene
}

National Cancer Institute

\section{Source}

National Cancer Institute. RHO/Gene. NCI Thesaurus. Code C106080.

This gene plays a role in both GTP hydrolysis and cytoskeletal remodeling. 